\title{
Effects of hydrogel application on growth of seedlings on unproductive forest areas
}

\author{
Andrzej Boczoń1 ${ }^{*}$, \\ Michał Wróbel ${ }^{1}$, \\ Wiesław Ptach ${ }^{2}$ \\ ${ }^{1}$ Forest Research Institute, Sękocin Stary, \\ ul. Braci Leśnej 3, 05-090 Raszyn, Poland \\ ${ }^{2}$ Warsaw University of Life Sciences, \\ Faculty of Engineering and \\ Environmental Science, \\ ul. Nowoursynowska 166, \\ 02-787 Warszawa, Poland
}

\begin{abstract}
The study focused on the influence of hydrogel on seedlings. Hydrogel is a good absorbent of macromolecule compound that can effectively bind water. The possibility of hydrogel to retain water is very important in the case of poor soils, especially when seedlings are growing in unfavorable drought conditions. From a theoretical point of view, hydrogel and its positive influence on survival and growth of seedlings is proved, but the question arises how it may affect, for instance, soil water increasing potential, reduction of mycorrhizas or pollution absorption. The investigation was conducted on areas difficult for afforestation, such as agricultural, after-military, post-industrial and post-drainage peat-bogs. The influence of hydrogel on soil moisture, $\mathrm{pF}$ curve, water consumption by seedlings was also observed under laboratory conditions and in greenhouse. Main objectives of the present study include detection of effects of hydrogel application on survival and growth processes of pine (Pinus sylvestris) seedlings.
\end{abstract}

Key words: hydrogels, seedlings, Pinus sylvestris, afforestation

\section{INTRODUCTION}

The part of grounds intended for afforestation is characterized by lack of moisture and alimentary substances. Such grounds may embrace, in particular, sandy soils that are poor in water and alimentary substances, dunes, postindustrial areas (sand pits, gravel pits, dumping grounds) and rotten peat as well. Bad conditions of growth in these areas lead to underdevelopment and decay of seedlings. In order to improve the parameters of soil, the application of resources capable to retain water and other alimentary ingredients in soil is necessary. One of comparatively new approaches improving the water economy of soil is the use of hydrogels, or synthetic polymer organic combinations called soil conditioners.

\section{DEFINITION OF THE PROBLEM}

Hydrogels can possibly improve the quality of water in upper layers of soil and at the same time create favorable conditions for the development of seedlings due to the fact that they can increase their growth and distinctly upgrade their state. Theoretically, however, there exist certain threats connected with the use of these compounds that may cause

* Corresponding author. E-mail: a.boczon@ ibles.waw.pl some undesirable effects in forest-trees seedlings in some cases. Hydrogels as combinations absorbing water exert the defined binding power of water particles, and as a consequence can cause the limitation in water collected by the seedlings in cases where the potential of soil water is greater than the power drawing of roots. The surrounding of roots because of the hydrogel can also act as a restrictive factor for occurrence of mycorrhizas. The symbiosis between trees and fungi is a basic condition for the correct water economy of forest-trees. Under those circumstances, when due to the presence of hydrogels mycorrhiza cannot be produced or its development is impaired, such trees are subject to stress if hydrogel reduces its own proprieties. It can bring about the dying away of saplings as a consequence of lack of the sufficient surface of receiving of water collected from the soil which under regular circumstances would ensure occurrence of mycorrhizas.

The project aims at defining the possibilities of use of hydrogels in grounds difficult for afforestation and, in particular, recognition of capacities of hydrogel with regard to:

- growth of seedlings,

- successful afforestation,

- soil humidity,

- retention proprieties of soils,

- water sucking by seedlings,

- occurrence of mycorrhizas. 


\section{THE SCOPE OF RESEARCH AND INVESTIGATION METHODS}

In order to achieve the established objectives of research, both laboratory tests and field investigation were conducted. The research work aimed at showing the impact of different hydrogel concentrations and investigation of its capacity to retain water by soil water absorption by seedlings was conducted in the laboratory as well as in the greenhouse. The ability of soil to retain water was recognized by means of moisture measurement of soil with the use of the Time Domain Reflectometry (TDR) method and through the implementation of $\mathrm{pF}$ curves using the dust-blocks Eijkelkamp and Soil Moisture Ltd pressure chambers. Water collection by seedlings was measured using the Flow4-System equipment produced by the Dynamax Inc.

In the course of field studies the influence of hydrogels upon the growth and life of seedlings as well as the occurrence of mycorrhizas was determined. Four field experiments were defined: two in the area of the Forest District Administration of Bełchatów and two within the confines of the Forest District Administration of Chocianów including:

- the post-farming grounds (the Forest District Administration of Bełchatów),

- the post-industrial area - dumping ground of the Brown Coal Mine of Bełchatów (the Forest District Administration of Bełchatów),

- the post-military grounds (The Forest District Administration of Chocianów),

- the grounds with the sapric histosols soil (The Forest District Administration of Chocianów).

In each experiment the grounds were forested with the Scots pine with a special attention drawn to five patches of land under investigation using the method of hydrogel application:

- Plot of ground 1 - the checking area without hydrogel,

- Plot of ground 2 - hydrogel applied through coating (soaking of the seedling radicular system with the water suspension of hydrogel),
- Plot of ground 3 - hydrogel applied as the subcrust under the seedling,

- Plot of ground 4 - hydrogel along with manure applied as the subcrust,

- Plot of ground 5 - hydrogel applied through mixing with the topsoil throughout the belt width.

In each plot of ground from 201 to 306 one-year seedlings of Scots pine were planted (Table 1). Upon planting the heights of all seedlings were carefully measured. After every vegetation period the measurement of the height was repeated and the number of living seedlings was defined.

The experiments were conducted using the pure formula of the hydrogel in the form of the Aquaterra product and the concoction prepared of the hydrogel and manure in the form of the TerraVit product, both made by the Terra-Gubin company. The present publication introduces the results of the growth of the seedlings and deftness of the afforestation upon the first vegetation season.

\section{THE RESEARCH RESULTS WITH REGARD TO DEFTNESS AND GROWTH RATE OF SEEDLINGS AFTER THE FIRST VEGETATION SEASON}

The experiment performed on the external dumping ground of the brown coal mine of "Bełchatów"

Figures 1-5 introduce histograms of the number of seedlings in each class of height on the plots located within the confines of the "Bełchatów" brown coal mine external dumping grounds where the experiment was conducted, and Table 1 shows some selected sizes featuring the planted population of seedlings. Each plot of ground encompasses a set ranging from 292 to 306 seedlings.

The area under survey comprised 292 planted seedlings. At the time of planting, seedlings of the heights ranging from $40 \mathrm{~mm}$ to $100 \mathrm{~mm}$ dominated. The dying away first of all concerned the seedlings smallest in size, and the number of dead seedlings decreased alongside the growing height of seedlings. In total, $90 \%$ of the planted seedlings survived after the first vegetation season. The seedlings in the area under survey attained the average increase of $31 \mathrm{~mm}$ in height in the

Table 1. Characteristics of afforestation areas (A - Control, B - Coating, C - Pure subcrust, D - Subcrust with manure, E - Areally)

\begin{tabular}{|c|c|c|c|c|c|c|c|c|c|c|c|c|c|c|c|}
\hline \multirow{2}{*}{ Description } & \multicolumn{5}{|c|}{ The dumping ground of the coal-pit } & \multicolumn{5}{|c|}{ The post-farming ground } & \multicolumn{5}{|c|}{ The post-military ground } \\
\hline & A & B & C & D & $\mathbf{E}$ & A & B & C & D & $\mathbf{E}$ & A & B & C & D & $\mathbf{E}$ \\
\hline $\begin{array}{l}\text { Number of planted seedlings } \\
\text { (pieces) }\end{array}$ & 292 & 298 & 306 & 301 & 294 & 272 & 263 & 261 & 288 & 267 & 208 & 205 & 201 & 210 & 202 \\
\hline $\begin{array}{c}\text { Average height } \\
\text { of planted seedlings (mm) }\end{array}$ & 82 & 93 & 101 & 83 & 80 & 130 & 138 & 141 & 129 & 127 & 74 & 67 & 72 & 65 & 79 \\
\hline $\begin{array}{l}\text { Surviving seedlings } \\
\text { upon one year (\%) }\end{array}$ & 90 & 93 & 85 & 72 & 89 & 86 & 64 & 61 & 93 & 88 & 91 & 92 & 43 & 68 & 85 \\
\hline $\begin{array}{l}\text { Average height } \\
\text { of surviving seedlings (mm) }\end{array}$ & 111 & 128 & 130 & 130 & 117 & 173 & 181 & 199 & 185 & 182 & 109 & 102 & 105 & 104 & 117 \\
\hline $\begin{array}{c}\text { Average growth rate } \\
\text { of surviving seedlings (mm) }\end{array}$ & 31 & 38 & 32 & 47 & 40 & 51 & 48 & 57 & 63 & 56 & 36 & 39 & 37 & 43 & 41 \\
\hline
\end{tabular}


course of the first vegetation year. After the vegetation season, most of the seedlings represented classes of the height ranging from 60 to $160 \mathrm{~mm}$.

On the plot of ground where the subcrusting of root systems involved hydrogel application (Fig. 2), 93\% of the 298 planted seedlings were alive after the vegetation season. The average height the planted seedlings had attained was $80 \mathrm{~mm}$. In the course of the vegetation season the height of living seedlings grew by about $38 \mathrm{~mm}$ on average. The most numerous group of the planted seedlings had a height between 60 and $120 \mathrm{~mm}$, another most numerous group of seedlings was about the height ranging from 80 to $180 \mathrm{~mm}$ and very few reached the height of $240 \mathrm{~mm}$ after the vegetation season was over.
In the area where hydrogel had been in use as the subcrust for 306 planted seedlings (Fig. 3), the greatest number of seedlings had attained the height ranging from 80 to $120 \mathrm{~mm}$. After the first vegetation season $15 \%$ of the seedlings decayed. Such dying away appeared first of all among saplings whose height did not exceed $100 \mathrm{~mm}$. The growth of seedlings during the first vegetation season resulted in the greatest number of seedlings that reached the height ranging from 80 to $180 \mathrm{~mm}$; the height of very few reached $240 \mathrm{~mm}$. The average increase in growth after the first vegetation season was $32 \mathrm{~mm}$.

301 seedlings were planted on the plot of ground where the concoction of hydrogel and manure was used as the subcrust (Fig. 4). In the first vegetation season $28 \%$ seedlings decayed. The dying away appeared mostly among seedlings

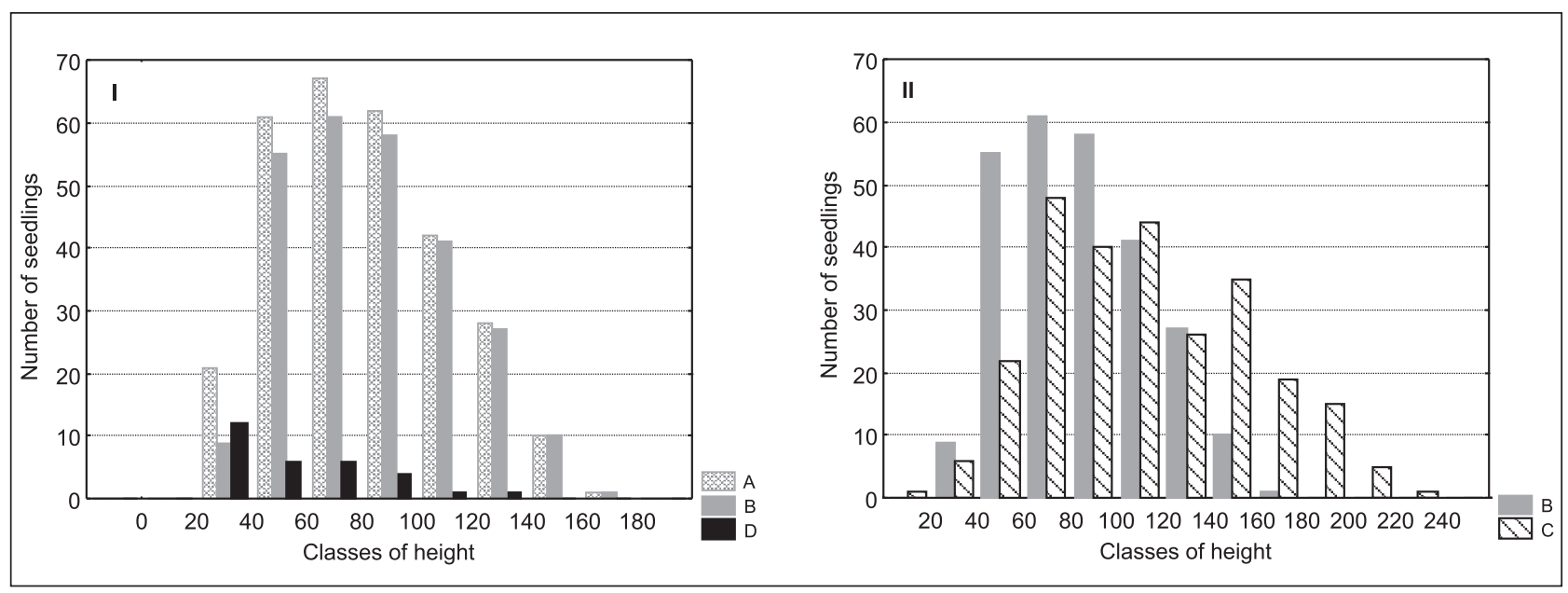

Fig. 1. The number of seedlings in different classes of height in Experimental plot 1 - control - on the "Bełchatów" brown coal mine dumping ground [I - first measurement of height (after planting): A - all seedlings, B - seedlings which survived till the second measurement, D - seedlings which had died before the second measurement; II - second measurement (after the first vegetation season): B - seedlings which survived till the second measurement, $C$ - heights of seedlings after the first vegetation season]

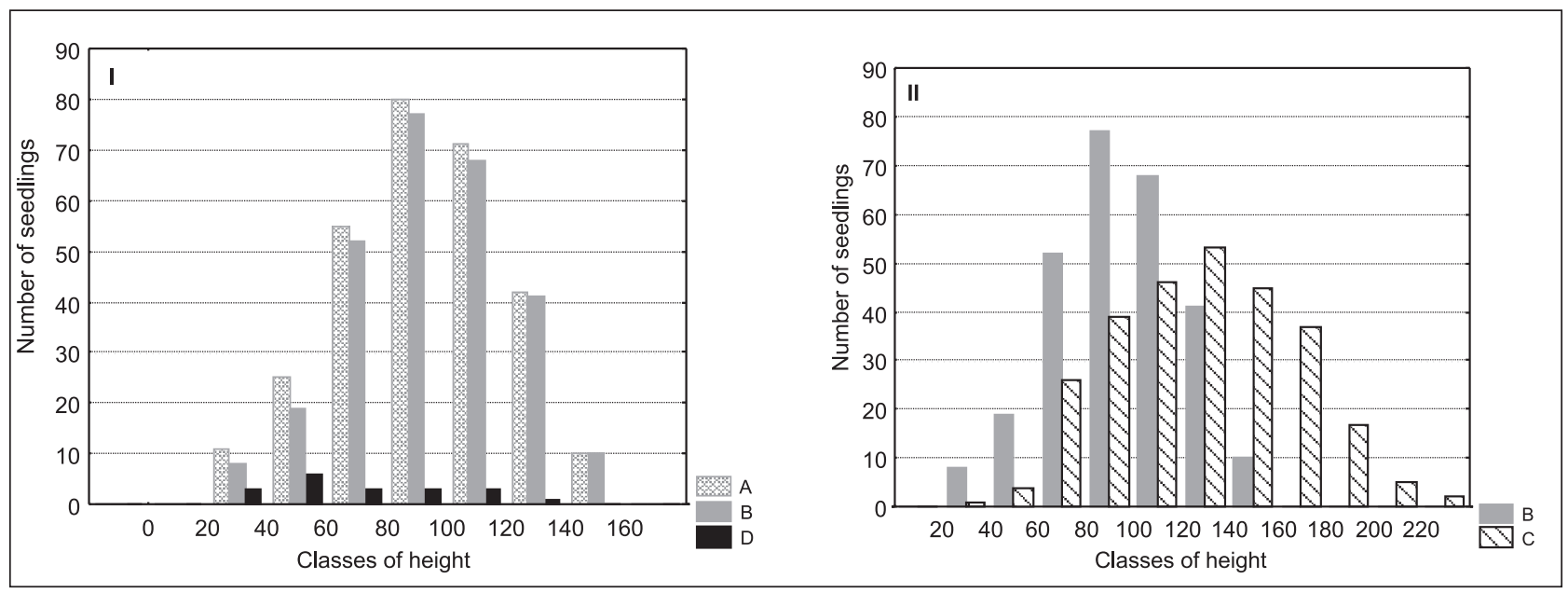

Fig. 2. The number of seedlings in various classes of height on Plot 2 - coating - on the "Bełchatów" brown coal mine dumping ground [I - first measurement of height (after planting): A - all seedlings, B - seedlings which survived till the second measurement, D - seedlings which had died before the second measurement; II - second measurement (after the first vegetation season): $B$ - seedlings which survived till the second measurement, $C$ - heights of seedlings after the first vegetation season] 


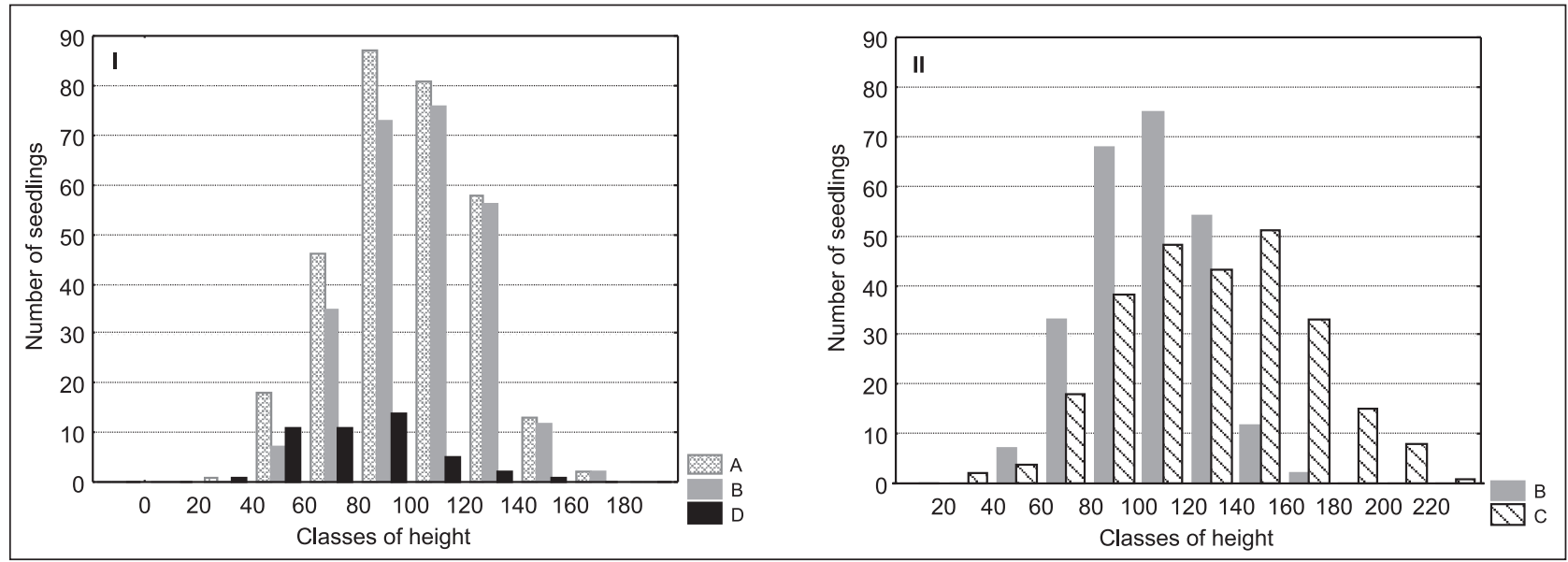

Fig. 3. The number of seedlings in classes of height on Plot 3 - subcrust - on the "Bełchatów" brown coal mine dumping ground [I - first measurement of height (after planting): A - all seedlings, B - seedlings which survived till the second measurement, D - seedlings which had died before the second measurement; II - second measurement (after the first vegetation season); B - seedlings which survived till the second measurement, $C$ - heights of seedlings after the first vegetation season]
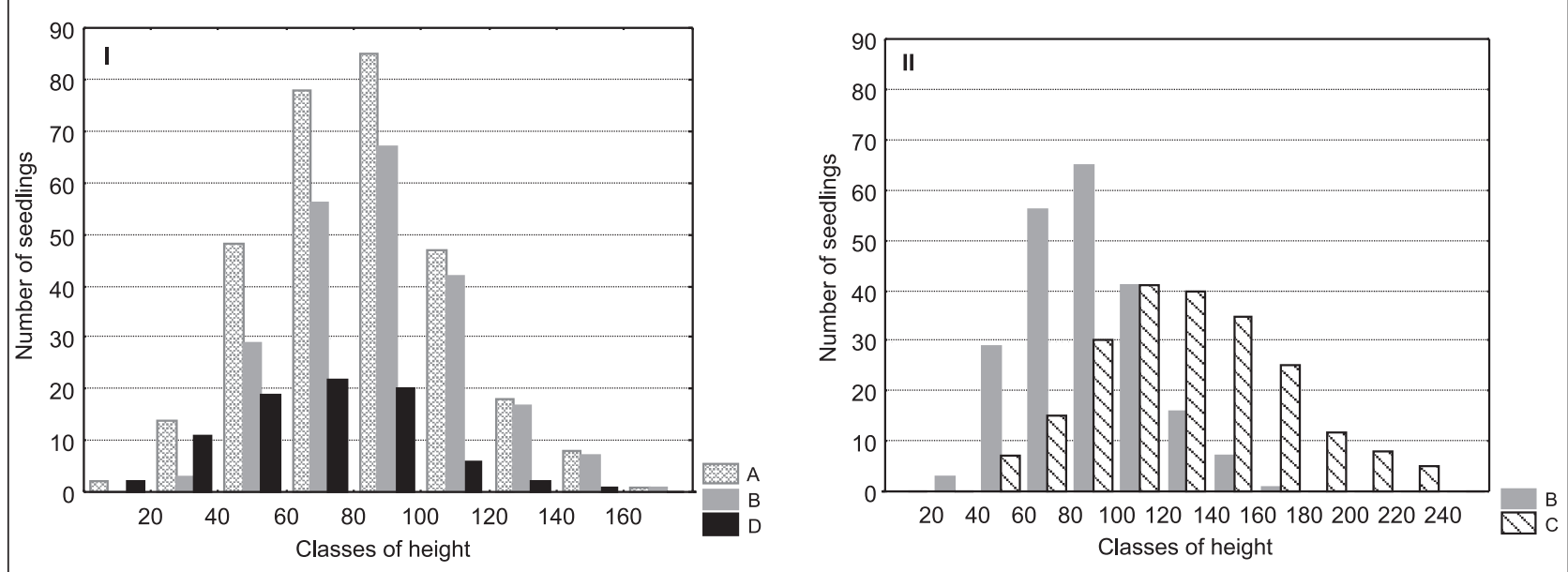

Fig. 4. The number of seedlings in classes of height on Plot 4 - subcrust with manure - on the "Bełchatów" brown coal mine dumping ground [I - first measurement of height (after planting): $A$ - all seedlings, B - seedlings which survived till the second measurement, D - seedlings which had died before the second measurement; II - second measurement (after the first vegetation season): B - seedlings which survived till the second measurement, $C$ - heights of seedlings after the first vegetation season]

of about $100 \mathrm{~mm}$ in height. At the time of planting the greatest number of seedlings had the height ranging from 60 to $100 \mathrm{~mm}$. After the first vegetation season the greatest number of seedlings reached between 80 to $180 \mathrm{~mm}$ and very few reached $240 \mathrm{~mm}$. The average height of seedlings which survived amounted to $47 \mathrm{~mm}$.

294 planted seedlings were planted on the plot of ground where the hydrogel was blended with the upper layer of soil throughout the planting beltwidth (Fig. 5). After the first vegetation year $89 \%$ of the seedlings survived. At planting the greatest number of seedlings ranged from 40 to $100 \mathrm{~mm}$ in height. On this plot of ground the steady decay was observed. After the first vegetation season the most significant group of seedlings ranged from 60 to $160 \mathrm{~mm}$ in height. The average growth rate of surviving seedlings in the first vegetation season amounted to $40 \mathrm{~mm}$.

\section{The experiment done on the post-farming ground}

Figures 6-10 represent some histograms with the number of seedlings in each class of height in plots of ground located on the experimental ground of the post-farming area. Table 1 introduces some selected sizes distinctive for planted population of seedlings. The area under survey embraces 272 planted seedlings (Fig. 6). At the time of planting the seedlings ranging from $100 \mathrm{~mm}$ to $160 \mathrm{~mm}$ in height predominated. After the first vegetation season $86 \%$ of the planted seedlings survived. Dying away of seedlings was greater among seedlings of height ranging from 80 to $120 \mathrm{~mm}$ and from 140 to $160 \mathrm{~mm}$. The average growth rate in height of seedlings in the course of the first vegetation year amounted to $51 \mathrm{~mm}$. After the vegetation season most of all the seedlings represented classes of height between 106 to $180 \mathrm{~mm}$. The seedlings of about $340 \mathrm{~mm}$ in height were noted. 

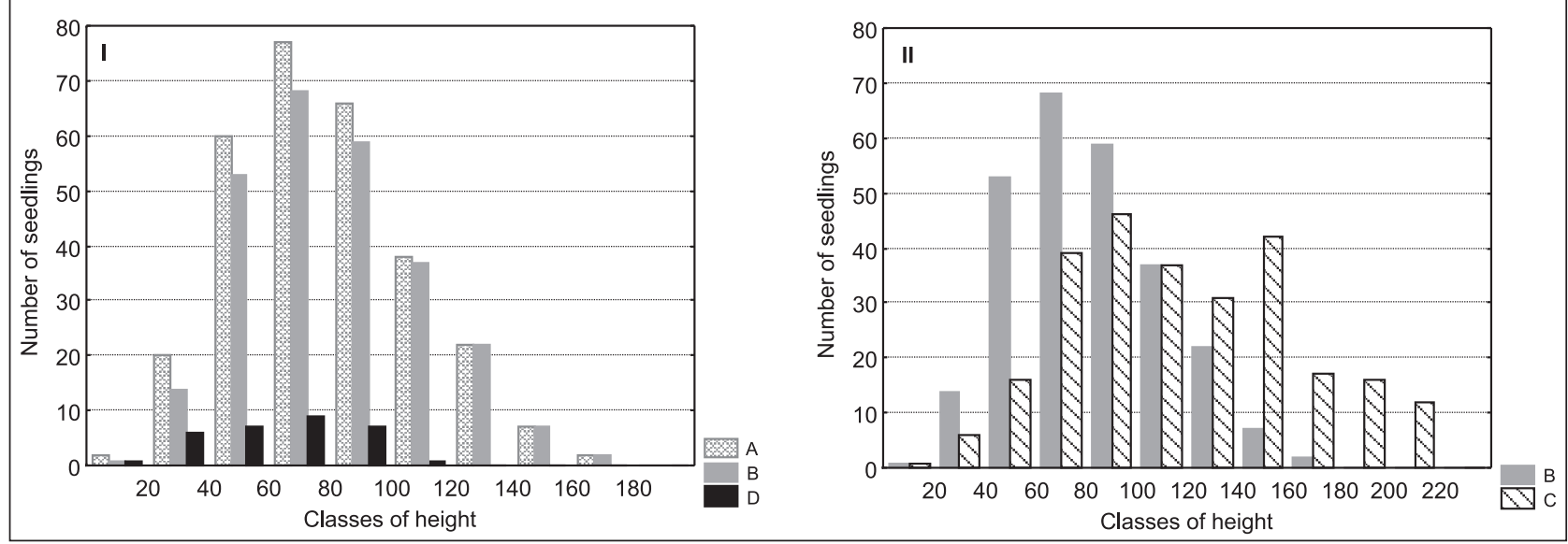

Fig. 5. The number of seedlings in classes of height on Plot 5 - areally - on the "Bełchatów" brown coal mine dumping ground [I - first measurement of height (after planting): A - all seedlings, B - seedlings which survived till the second measurement, D - seedlings which had died before the second measurement; II - second measurement (after the first vegetation season): $B$ - seedlings which survived till the second measurement, $C$ - heights of seedlings after the first vegetation season]
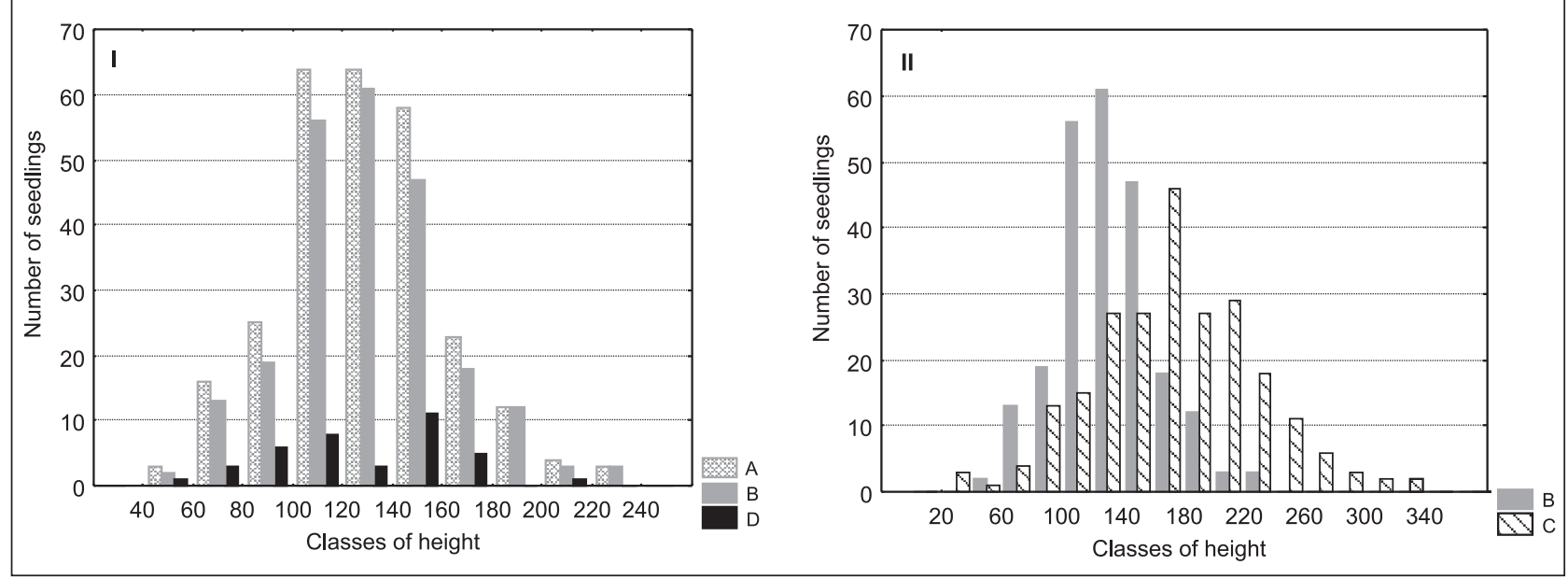

Fig. 6. The number of seedlings in classes of height on Plot 1 - control - on the post-farming ground [I - first measurement of height (after planting): A - all seedlings, $B$ - seedlings which survived till the second measurement, $D$ - seedlings which had died before the second measurement; II - second measurement (after the first vegetation season): $B$ - seedlings which survived till the second measurement, $C$ - heights of seedlings after the first vegetation season]
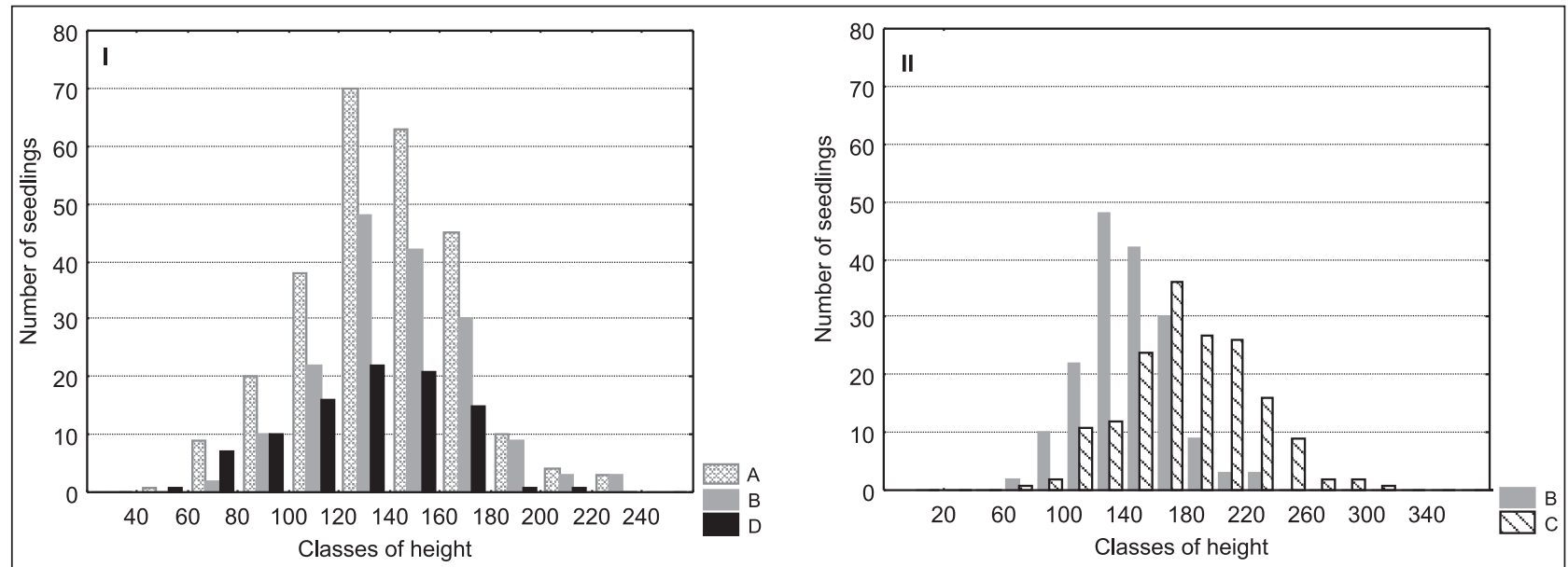

Fig. 7. The number of seedlings in classes of height on Plot 2 - coating - on the post-farming ground [I - first measurement of height (after planting): A - all seedlings, $B$ - seedlings which survived till the second measurement, D - seedlings which had died before the second measurement; II - second measurement (after the first vegetation season): $B$ - seedlings which survived till the second measurement, $C$ - heights of seedlings after the first vegetation season] 
On the plot of ground where coating of radicular systems using hydrogel was applied (Fig. 7), 64\% out of 263 planted seedlings survived after vegetation season. The average height of planted seedlings attained $138 \mathrm{~mm}$. In the course of vegetation season, the height of surviving seedlings increased on average by about $48 \mathrm{~mm}$. The largest group of planted seedlings attained heights varying from 120 to $160 \mathrm{~mm}$ after vegetation season with the prevailing group of seedlings of height ranging from 160 to $220 \mathrm{~mm}$; a few of them reached $320 \mathrm{~mm}$.

The surface area where hydrogel was applied as the subcrust on 261 planted seedlings (Fig. 8). The majority of seedlings attained the height ranging from 100 to $160 \mathrm{~mm}$. After the first vegetation season $40 \%$ of the seedlings decayed. Such dying away was observed in all classes of height. The height of seedlings in the first vegetation season contributed to the fact that the prevailing number of seedlings reached heights varying from 140 to $240 \mathrm{~mm}$ and very few arrived at $340 \mathrm{~mm}$. The average growth rate after the first vegetation season amounted to $57 \mathrm{~mm}$.

288 seedlings were planted on the plot of ground where the applied subcrust was composed of the mixture of hydrogel and manure together (Fig. 9). In the first vegetation season $7 \%$ of the seedlings decayed. The dying away appeared evenly in all classes of height. At the time of planting the majority of seedlings were of the height ranging from 80 to $160 \mathrm{~mm}$. After the first vegetation season most of the seedlings reached heights from 120 to $220 \mathrm{~mm}$ and from 260 to $280 \mathrm{~mm}$ and very few were $360 \mathrm{~mm}$ in height. The average growth rate of seedlings that survived measured up to $63 \mathrm{~mm}$.

On the plot of ground where the hydrogel had been blended with the upper layer of soil throughout the plant-
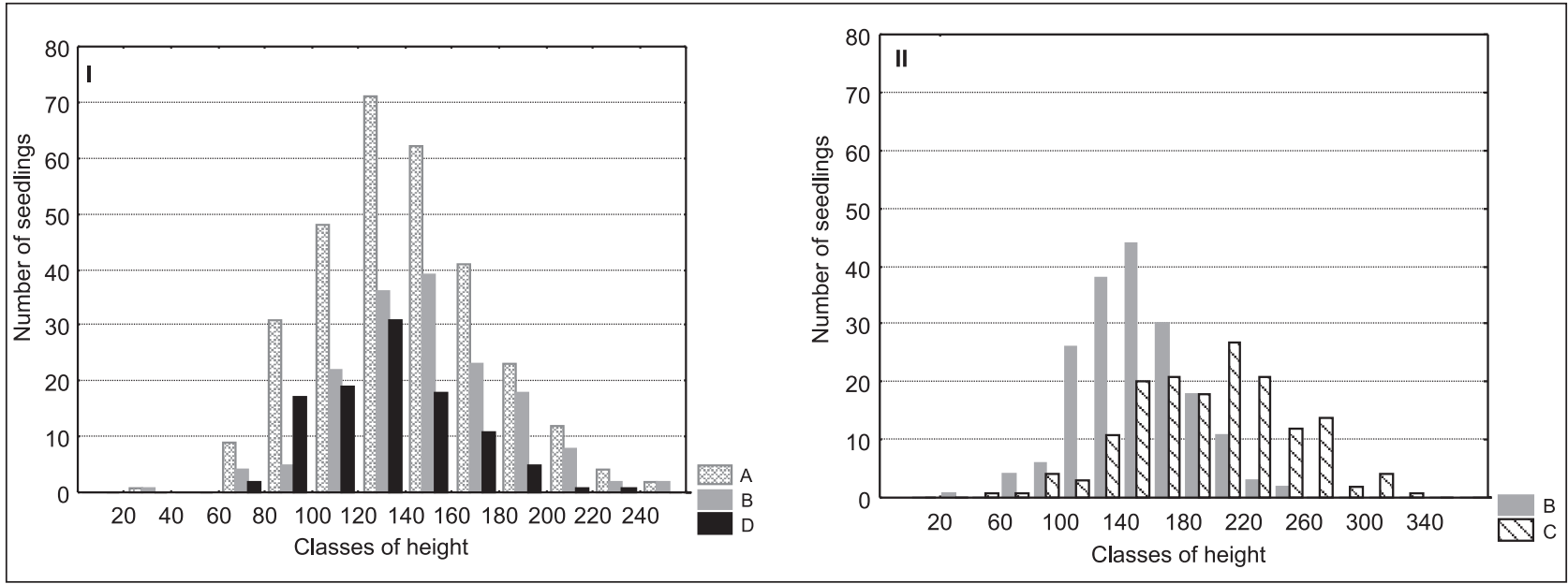

Fig. 8. The number of seedlings in classes of height on Plot 3 - subcrust - on the post-farming ground [I - first measurement of height (after planting): A - all seedlings, $B$ - seedlings which survived till the second measurement, D - seedlings which had died before the second measurement; $I I$ - second measurement (after the first vegetation season): $B$ - seedlings which survived till the second measurement, $C$ - heights of seedlings after the first vegetation season]

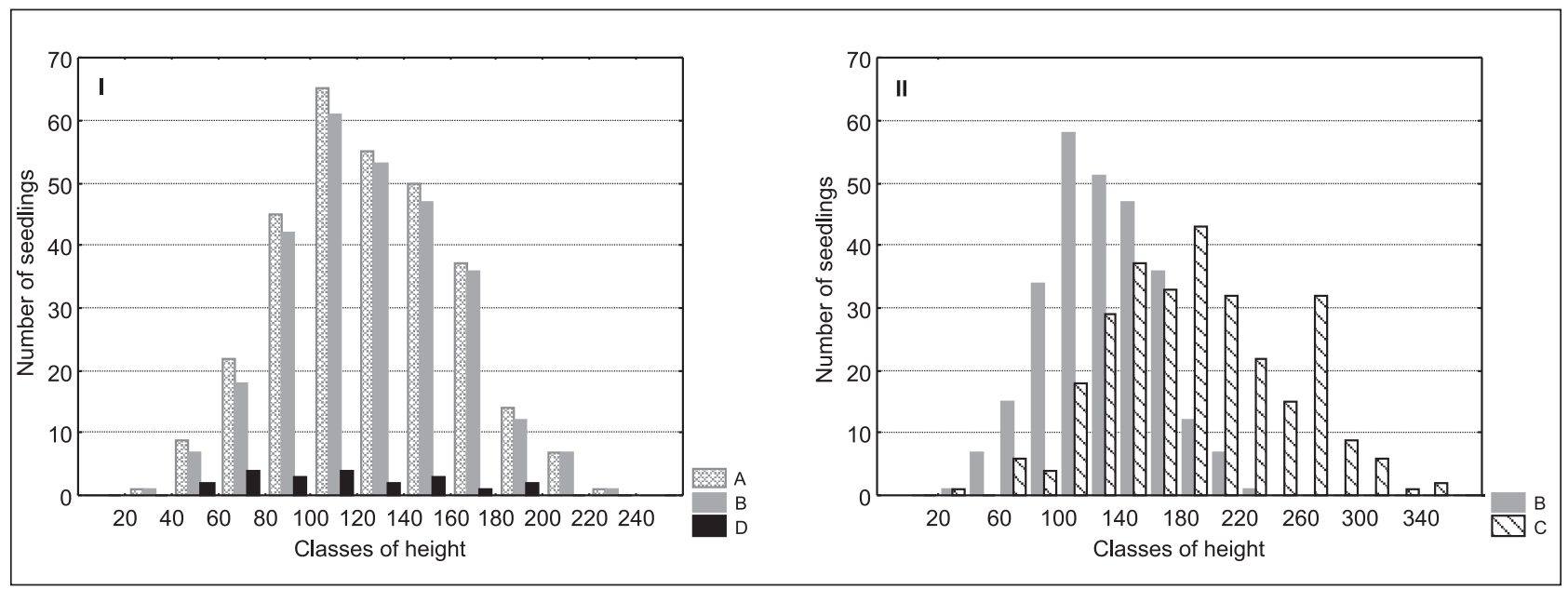

Fig. 9. Number of seedlings in classes of height on Plot 4 - subcrust with manure - on the post-farming ground [I - first measurement of height (after planting): A - all seedlings, B - seedlings which survived till the second measurement, D - seedlings which had died before the second measurement; II - second measurement (after the first vegetation season): $B$ - seedlings which survived till the second measurement, $C$ - heights of seedlings after the first vegetation season] 
ing belt width, 267 seedlings were planted (Fig. 10). After the first vegetation year, $88 \%$ of the seedlings survived. At planting, the greater number of seedlings ranged between 80 and $160 \mathrm{~mm}$ in height. Steady decay was observed on this plot of ground. After the first vegetation season, the prevailing group of seedlings varied from 140 to $240 \mathrm{~mm}$ in height. The average growth rate of surviving seedlings in the vegetation season amounted to $56 \mathrm{~mm}$.

\section{The experiment carried out on the post-military ground}

Figures 11-15 introduce the histograms referring to the number of seedlings in each class of height on plots of ground located on the previous army range where the experiment was held. Table 1 presents some selected distinctive features of the planted population of seedlings. The surface area under survey encompassed 208 planted seedlings characterized by the height within the range $40-80 \mathrm{~mm}$ (Fig. $11 \mathrm{I}$ ). After vegetation season, these values grew and heights of surviving seedlings varied significantly within 60-160 mm (Fig. 11 II). Also, the seedlings of about $200 \mathrm{~mm}$ in height were observed. $91 \%$ of the planted saplings survived on this area. The average growth rate in the height of the seedlings which survived amounted to $36 \mathrm{~mm}$.

The comparable height distribution was observed on the plot of ground where the seedlings coating method had been applied. (Fig. 12 I, II). Most of the planted saplings achieved heights within the range of $40-80 \mathrm{~mm}$, and after vegetation season the range of heights extended from 60 to $140 \mathrm{~mm}$. Similarly, the number of dead seedlings (8\%) was insignificant on the plot under survey. In each investigated class of height it did not exceed 10 items. The average increase of height of living seedlings reached $39 \mathrm{~mm}$.
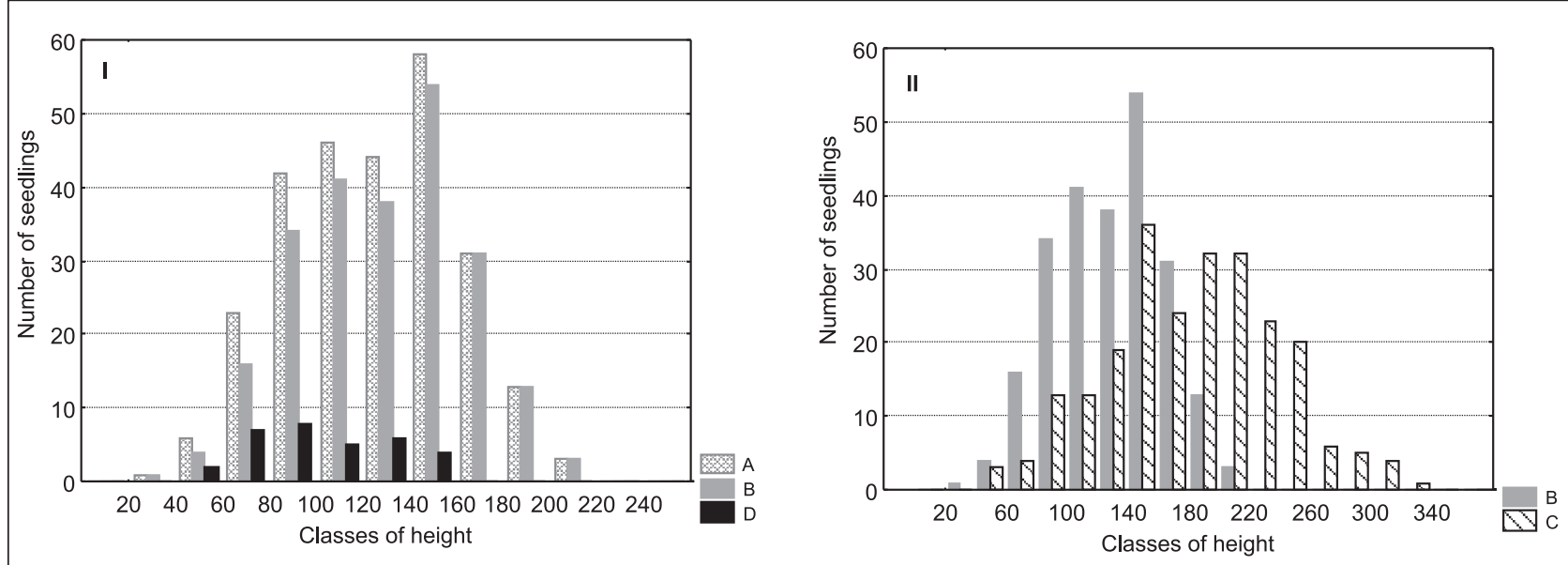

Fig. 10. The number of seedlings in classes of height on Plot 5 - areally - on the post-farming ground [I - first measurement of height (after planting): A - all seedlings, $B$ - seedlings which survived till the second measurement, $D$ - seedlings which had died before the second measurement; II - second measurement (after the first vegetation season): $B$ - seedlings which survived till the second measurement, $C$ - heights of seedlings after the first vegetation season]

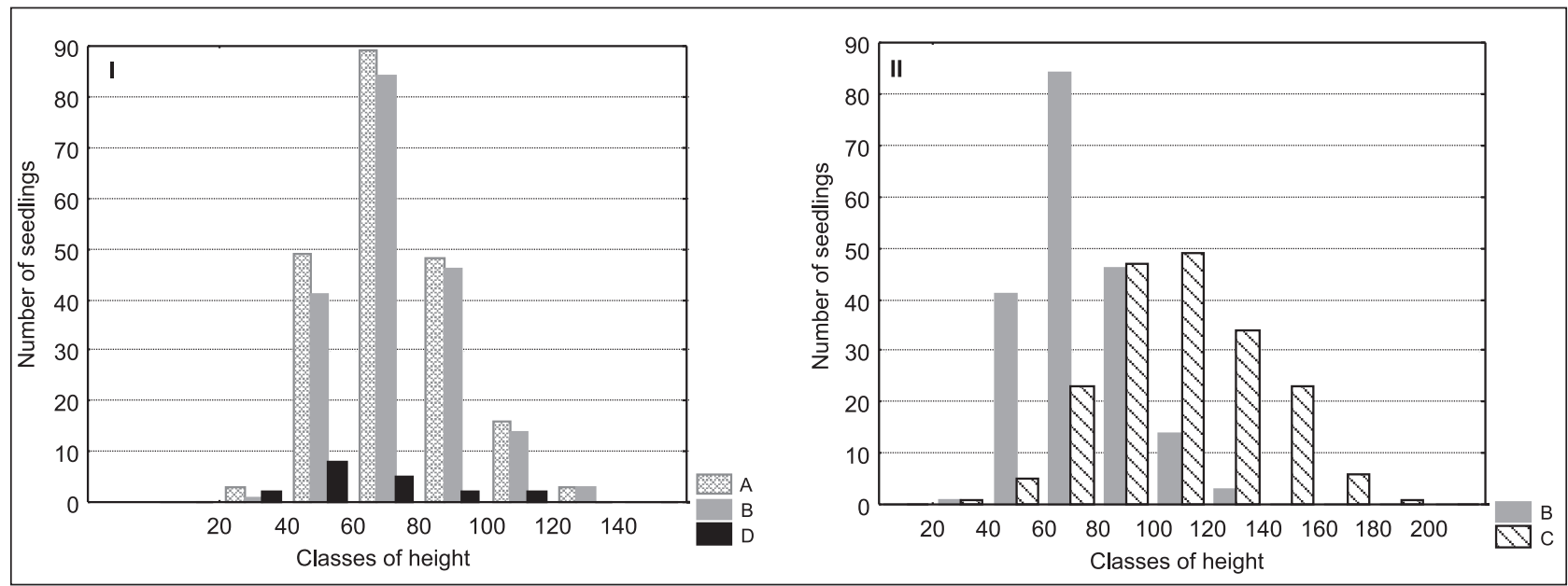

Fig. 11. The number of seedlings in classes of height on Plot 1 - control - the post-military ground [I - first measurement of height (after planting): A - all seedlings, $B$ - seedlings which survived till the second measurement, $D$ - seedlings which had died before the second measurement; II - second measurement (after the first vegetation season): $B$ - seedlings which survived till the second measurement, $C$ - heights of seedlings after the first vegetation season] 
The subcrust method of hydrogel applied at planting under the sapling contributed to the least rate of survival, i. e. $-42 \%$. (Fig. 13 I). At planting, the height of seedlings varied between about 40 and $80 \mathrm{~mm}$. After vegetation period, the height of surviving seedlings increased in comparison with their condition after planting and varied within the range of $80-120 \mathrm{~mm}$ (Fig. $13 \mathrm{II}$ ). Some seedlings far exceeded in height the others and ranked within the range from 200 to $220 \mathrm{~mm}$. The average increase of height of seedlings that survived amounted to $37 \mathrm{~mm}$. On the plot of ground where hydrogel mixed additionally with manure was applied, the saplings belonging to classes of height ranging from 40 to $80 \mathrm{~mm}$ were planted (Fig. $14 \mathrm{I}$ ). After the first vegetation season, $68 \%$ of seedlings survived. After the period of vege- tation the seedlings which survived ranged broadly in height and varied within the scope of 40-220 mm (Fig. 14 II), while the largest group of saplings' height fell in the range of 80 to $120 \mathrm{~mm}$. The average increase of the height of the surviving seedlings amounted to $43 \mathrm{~mm}$.

The method of face blending of hydrogel was used in the last experimental plot of ground; heights of planted saplings varied from 40 to $120 \mathrm{~mm}$ and only a few saplings died (Fig. 15 I). There $15 \%$ of the seedlings decayed. During the first vegetation period the seedlings reached heights within 40-240 mm, and the largest group classified as 80 to $120 \mathrm{~mm}$ in height. A small part of seedlings arrived at $240 \mathrm{~mm}$ in height. The average increase in growth rate of living saplings amounted to $41 \mathrm{~mm}$.

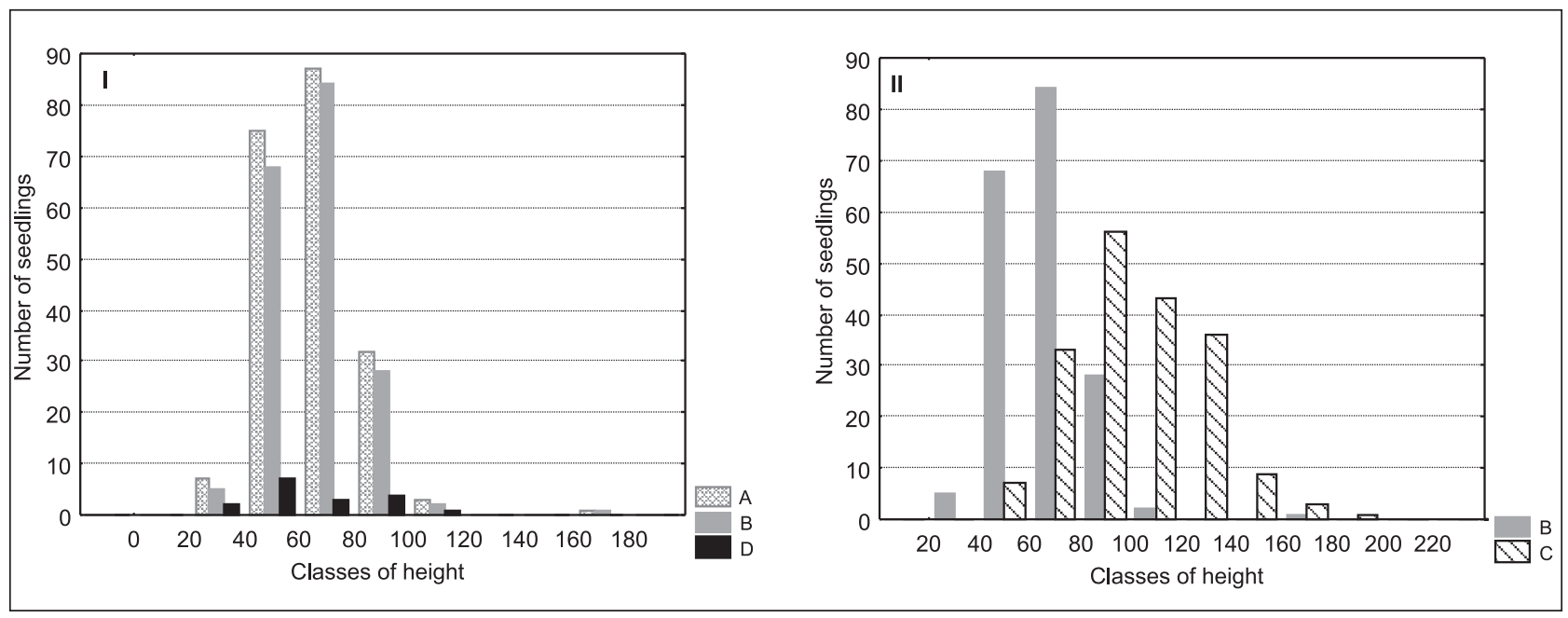

Fig. 12. The number of seedlings in classes of height on Plot 2 - coating - the post-military ground [I - first measurement of height (after planting): A - all seedlings, $B$ - seedlings which survived till the second measurement, $D$ - seedlings which had died before the second measurement; II - second measurement (after the first vegetation season): $B$ - seedlings which survived till the second measurement, $C$ - heights of seedlings after the first vegetation season]

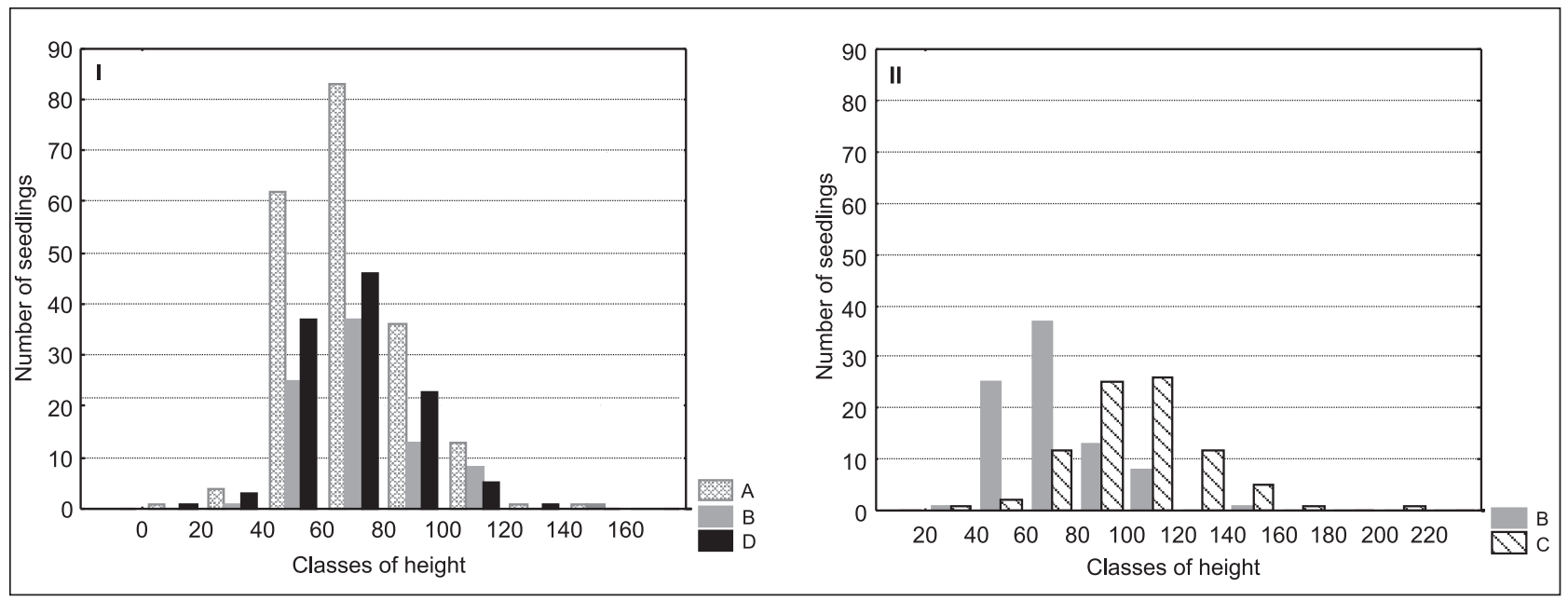

Fig. 13. The number of seedlings in classes of height on Plot 3 - subcrust - the post-military ground [I - first measurement of height (after planting): A - all seedlings, B - seedlings which survived till the second measurement, D - seedlings which had died before the second measurement; II - second measurement (after the first vegetation season) $B$ - seedlings which survived till the second measurement, $C$ - heights of seedlings after the first vegetation season] 


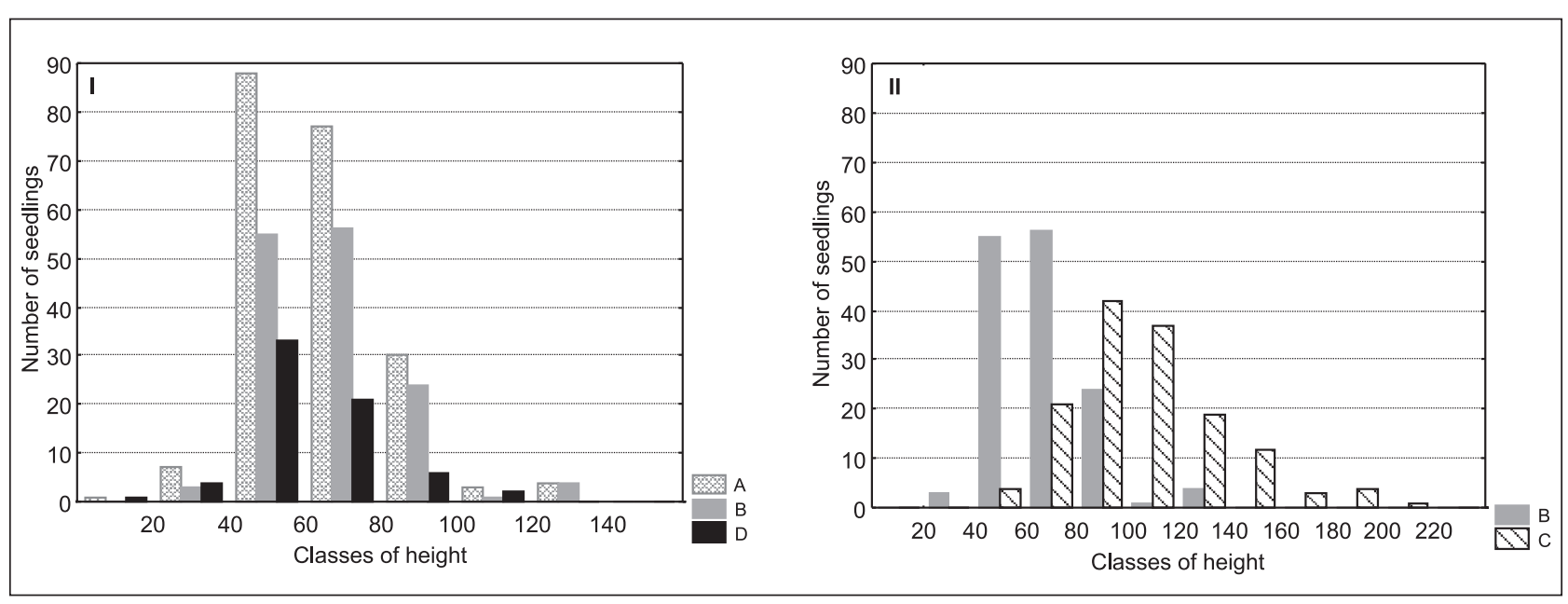

Fig. 14. The number of seedlings in classes of height on Plot 4 - subcrust with manure - the post-military ground [I - first measurement of height (after planting): A - all seedlings, B - seedlings which survived till the second measurement, D - seedlings which had died before the second measurement; $I I$ - second measurement (after the first vegetation season): $\mathrm{B}$ - seedlings which survived till the second measurement, $\mathrm{C}$ - heights of seedlings after the first vegetation season]

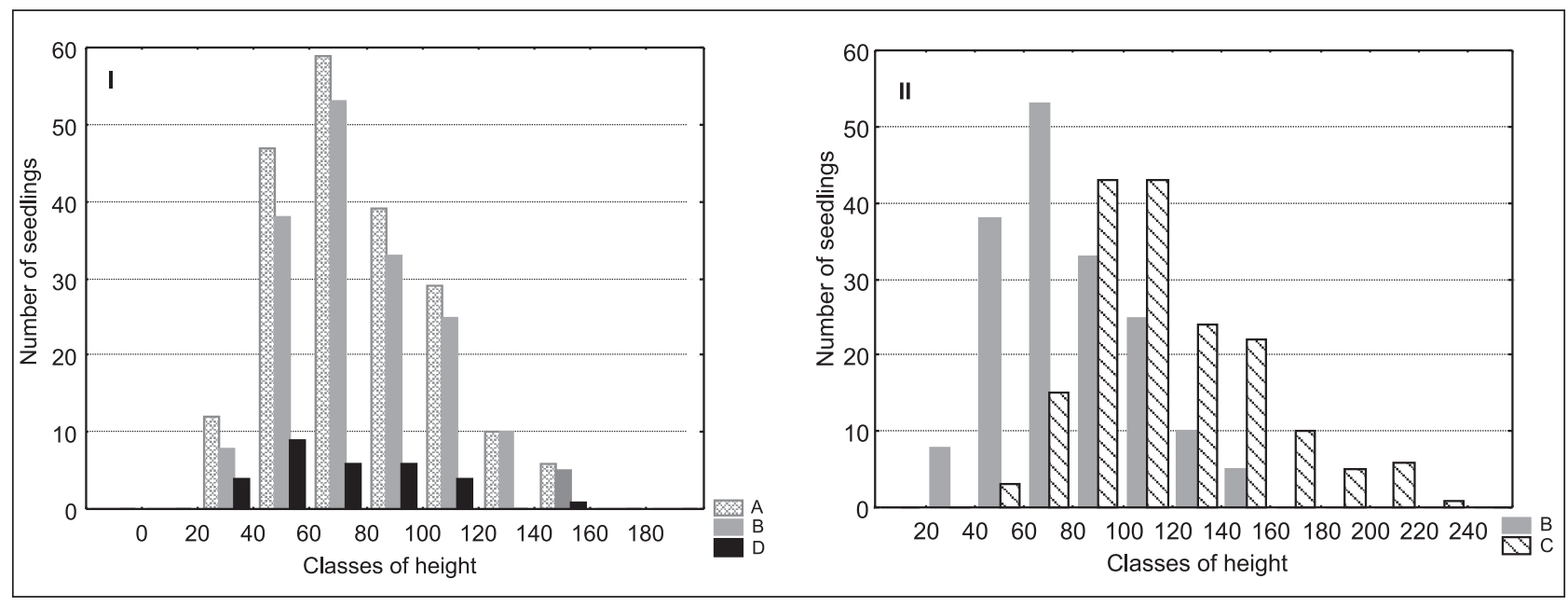

Fig. 15. The number of seedlings in classes of height on Plot 5 - areally - the post-military ground [I - first measurement of height (after planting): A - all seedlings, $B$ - seedlings which survived till the second measurement, $D$ - seedlings which had died before the second measurement; II - second measurement (after the first vegetation season): $B$ - seedlings which survived till the second measurement, $C$ - heights of seedlings after the first vegetation season]

\section{Experiment carried out with the rotten peat}

This paper does not include the results of measurement taken from the experimental ground located on rotten peat bogs, because in the course of the first vegetation season a considerable number of the planted seedlings became severely damaged by the game. In such circumstances the obtained results could be erroneous and untrue. On the surface area in question the measurement will be maintained and observed with regard to the capability of regenerating the seedlings and checking the height of undamaged seedlings.

\section{DISCUSSION}

The first year of growth is a difficult time for seedlings. The change of environmental conditions of growth from ideal ones (that are present in schools created by the man) to natu- ral - i. e. existing in forests, often leads to weakening of seedlings and their dying away. Especially unfavorable conditions for growth were manifested on grounds where the experiment was conducted. Furthermore, the use of hydrogel also served as a very stressful factor for seedlings.

And therefore the study (if continued further in the following years) should be carried out based on the seedlings which have already adapted to the environmental conditions characteristic of tillages and this would be a turning point in showing the significant influence of hydrogel on the growth and survival of seedlings.

Until now the studies concerning the use of hydrogels have mainly been conducted with regard to agricultural and horticultural cultivation. Such surveys dealing with improvement of water retention in sandy soils through the usage of admixtures of polymer compositions were undertaken by 
a number of authors (Silberbuch et al., 1993a, 1993b; Pierzgalski, Ptach, 1999; Ziuz et al., 1990). The obtained results showed the significant increase of the water retention capacity in the radicular zone of the soil profile and the distinctive limitation of loss of water and manure as a consequence of leakages.

Few researches have been conducted treating the use of these resources in the forestry. One of the very first experiments took place in Arizona State where in the years 1972-1973 deftness of the germination of seeds and survival of the grown ups of Pinus ponderoza were observed (Rietveld, 1976). Some researches included applying of hydrogels in woody nursery practices (Sarvaš 2003; Sarvaš, Tucekova, 2003). Hydrogels were also investigated on unproductive areas (Buckstrup, Bassuk, 2000; Grabosky, Bassuk, 1995; Kahl et al.., 2000).

In research with Norway spruce and beech seedlings, the hydrogel content significantly affected the fresh weight of root system, but no significant differences could be found between seedlings grown (Puhlova, Smelkova, 1998). The application of hydrogels is simple but it is quite difficult not to overdose, which causes plant mortality (Sarvaš et al., 2007). Authors suggested that research should be carried out to determine suitable doses for different soil types and tree species.

\section{CONCLUSIONS}

After the first year of fieldwork research it is difficult to firmly and undoubtedly indicate the best method of usage of hydrogels, or to show which of the methods can provide the best results as to the growth or survival of seedlings. On the mining dumping ground the greater seedlings survival rate (as related to the supervised experimental area) proved strong advantages of the hydrogel use by means of coating. Therefore, the results received from the surface area after mixing hydrogel with upper layer of soil have been comparable. In other experiments the life of seedlings was shorter. As to the post-farming ground the survival appeared stronger with the usage of both the hydrogel and manure blended together with the upper layers of soil. As for the post-military ground, better survival was apparent only in the case of coating.

The enlarged growth rate effect regarding the surveyed area of the mining dumping ground was noted in the cases when the hydrogel was used regardless of the way of its application. Therefore the better results of growth rate were obtained with both the hydrogel and manure together. On the other hand, with regard to the post-farming ground, in the case of coating the growth rate on the surveyed area was lower, on the remaining areas the growth rate seemed higher. However, the best results were obtained when the subcrust of hydrogel and manure was used. The post-military ground did not vary that much as to the seedlings' growth rate on all plots of ground, the increase rate being more significant when compared to the testing plot of ground. Also, there better indicators were manifested upon the usage of the subcrust of hydrogel and manure.

\section{ACKNOWLEDGEMENTS}

This work was supported by Grant N30901731 / 2389 of the Polish Ministry of Science and Higher Education.

Received 20 October 2008 Accepted 29 January 2009

\section{References}

1. Buckstrup M. J., Bassuk N. L. 2000. Transplanting success of balled-and-burlapped versus bare-root trees in the urban landscape. Journal of Arboriculture. Vol. 26(6). P. 298-308.

2. Grabosky J., Bassuk N. 1995. A new urban tree soil to safely increase rooting volumes under sidewalks. Journal of Arboriculture. Vol. 21(4). P. 187-201.

3. Kahl L., Kluge R., Thomas S., Huttl R. F., Bradshaw A. D. (ed.). 2000. Evaluation of an attempt to cultivate shrubs and trees on a heap of a potash mine. Landscape \& Urban Planning. Vol. 51(4). P. 2-4, 109-112.

4. Pierzgalski E., Ptach W. 1999. New techniques in subsurface irrigation. Proceedings of ICID International Symposium: New Approaches in Irrigation, Drainage and Flood Control Management. CD. Bratislava, Slovak Republic. 37 p.

5. Puhlova I., Smelkova L. 1998. Vplyv hydroabsorbentu TerraCottem na rast semenacikov smreka obycajneho (Picea abies L. Karst.) a buka lesneho (Fagus sylvatica L.). Lesnictvi. Vol. 44(1). P. 10-15.

6. Rietveld W. J. 1976. Hydrophilic polymer reduces germination of Ponderosa Pine in seed spots. Tree Planters' Notes. Vol. 27. P. 18-19.

7. Sarvaš M. 2003. Effect of desiccation on the root system of Norway spruce (Picea abies [L.] Karst) seedlings and a possibility of using hydrogel STOCKOSORB for its protection. Journal of Forest Science. Vol. 49(11). P. 531-536.

8. Sarvaš M., Tucekova A. 2003. Aplikacia hydrogelov rady STOCKOSORB v skolkarskej vyrobe. Zprávy Lesneho Výzkuma. Vol. 48(2/3). P. 71-74.

9. Sarvaš M., Pavlenda P., Takáčová E. 2007. Effect of hydrogel application on survival and growth of pine seedlings in reclamations. Journal of Forest Science. Vol. 53(5). P. 204-209.

10. Silberbusch M., Adar E., De Malach Y. 1993a. Use of a hydrophilic polymer to improve water storage and availability to crops grown in sand dunes. I. Corn irrigated by trickling. Agricultural Water Management. Vol. 23. P. 303-313.

11. Silberbusch M., Adar E., De Malach Y. 1993b. Use of a hydrophilic polymer to improve water storage and availability to crops grown in sand dunes. II. Cabbage irrigated by sprinkling with different water salinities. Agricultural Water Management. Vol. 23. P. 315-327.

12. Ziuz N. S., Lazarev A. A., Kazanskiy K. S., Rakova G. V. 1990. An attempt to apply hydrogels to increase quartz sands water capacity. Pochvovedenie. Vol. 7. P. 149-153. 
Andrzej Boczoń, Michał Wróbel, Wiesław Ptach

\section{HIDROGELIO ITAKA DAIGAMS NEPRODUKTY-} VIUOSE MIŠKO PLOTUOSE

Santrauka

Tyrimo metu daugiausia dèmesio buvo skiriama hidrogelio ịtakai daigams. Hidrogelis kaip makromolekulès junginio absorbentas gali efektyviai surišti vandenị. Hidrogelio savybès surišti vandeni yra labai svarbios esant skurdžiam dirvožemiui, ypač kai daigai auga nepalankiomis sausros sąlygomis. Teoriškai hidrogelis turi teigiamą ịtaką daigu išlikimui ir augimui, tačiau būti- na nustatyti neigiamą jo ịtaką, pavyzdžiui, dirvožemio vandens potencialo didinimui, mikorizès mažinimui arba taršos absorbavimui. Tyrimas buvo atliktas sudètingose miško želdinimui teritorijose, t. y. žemès ūkio, buvusiose karinèse ir pramoninèse, nusausintuose durpynuose. Hidrogelio ịtaka dirvožemio drègniui, $\mathrm{pF}$ kreivei, vandeniui, daigams tirta laboratorinèmis sąlygomis ir šiltnamyje. Pagrindinis šio tyrimo tikslas - nustatyti hidrogelio taikymo efektą pušies (Pinus sylvestris) daigu išlikimui ir augimo procesams.

Raktažodžiai: hidrogeliai, daigai, Pinus sylvestris, miško želdinimas 